\title{
O Ensino do Direito Intelectual nas Universidades
}

\author{
Newton Silveira \\ Professor Assistente Doutor junto ao Departamento \\ de Direito Comercial da FADUSP e Membro \\ Fundador da ATRIP International Association \\ For The Advancement of Teaching And Research \\ in Intellectual Property.
}

A expressão direito intelectual é compreensiva da propriedade industrial, direitos de autor e matérias afins. Nesse mesmo sentido é empregada pelos autores italianos a denominação direito industrial (expressão também utilizada no Departamento de Direito Comercial da FADUSP, devido à influência dos comercialistas italianos em nossa Faculdade), se bem que enfeixando tais direitos no estabelecimento comercial, tomado como ponto de referência daquelas diversas instituições ${ }^{1}$. A expressão mais tradicional, destinada a abranger os direitos de autor e a propriedade industrial, é propriedade intelectual, adotada no título da OMPI - Organização Mundial da Propriedade Intelectual, e mesmo no da ATRIP (International Association for the Advancement of Teaching and Research in Intellectual Property), sem que isso, entretanto, possa significar uma adesão incondicional à teoria da propriedade sobre os bens imateriais.

O importante é destacar que no mundo de hoje a separação estanque entre o Direito de Autor (como ramo do Direito Civil) e a Propriedade Industrial (como matéria compreendida pelo Direito Comercial) não mais encontra razão de ser, como assinalei em trabalho anterior sobre o mesmo tema ${ }^{2}$.

Naquele trabalho se demonstrava que, sob o ângulo do direito que detém o autor sobre sua obra, nenhuma diferença existe entre o direito do inventor e o do autor de obra artística, direitos de mesma

1. TULLIO ASCARELLI, em seu Tratado da Concorrencia e dos Bens Imateriais, nega que essas instituições possam ser ordenadas convenientemente sob o perfil da composição da "azienda" ou da organização da empresa, colocando o acento da disciplina "sobre o interesse geral do progresso cultural e técnico e sobre o interesse do consumidor".

2. "O Direito Industrial e Sua Caracterização Como Ramo Antônomo do Direito Privado", RDM n॰ 36 , p. 60 e segs., trabalho esse também apresentado em Genebra, por ocasıão da fundação da ATRIP. 
natureza, tendo por objeto um bem imaterial resultante do exercício da criatividade humana. Além de possuir o inventor os chamados direitos morais (que, em conseqüência, não são faculdade exclusiva do autor de obra literária ou artística), estudos mais recentes sobre o segredo industrial e a transferência de tecnologia evidenciaram também um direito de inédito do inventor, desfazendo-se, assim, a pretensa diferenciação de naturezas dos direitos de propriedade industrial e de autor.

Sob o enfoque do estabelecimento comercial, a ele se agregam tanto os direitos sobre as criações técnicas, como os relativos às criações artísticas, podendo quaisquer deles ser objeto dos negócios jurídicos realizados pelo empresário, sejam negócios de alienação, ou de licença de exploração (nestes compreendida a adição), independentemente de tratarem de invenções, modelos, sinais distintivos ou obras artísticas (é fato notório que as mais importantes indústrias atuais têm como produto as obras literárias, as músicas, como as denominadas indústria editorial e indústria fonográfica, tendendo mesmo a que o produto mais importante de nossa época seja a própria cultura).

$O$ tratamento legal diferenciado que ainda recebem os direitos de autor, de um lado, e a propriedade industrial, de outro, enseja perplexidades, como a atual crise do enquadramento jurídico do "software", já que a incidência sobre essa nova modalidade de criação intelectua] das normas do direito autoral permitiria incontrolada evasão de divisas, situação essa não prevista pelo legislador.

A questão da autonomia da disciplina do direito intelectual (ou direito industrial, ou propriedade intelectual) foi tratada em maior profundidade em meu artigo já referido, que concluía pela necessidade do reconhecimento de sua autonomia didática, devendo compreender o estudo do direito de autor, da propriedade industrial, da concorrência desleal, transferência de tecnologia e defesa do consumidor.

Em sua obra referida, advertia já Ascarelli sobre a vinculação entre o desenvolvimento econômico e a importância cada vez maior dos problemas de direito industrial, "que adquirem tão maior importância quanto mais desenvolvida esteja a industrialização do país e mais ativa seja a luta da concorrência", não se devendo esquecer "a elaboração de princípios diretores, especialmente necessários em uma disciplina que imediatamente se põe em conexão com o desenvolvimento econômico do país".

Nosso empenho em ver reconhecida a autonomia do direito intelectual e a necessidade de seu ensino nas faculdades brasileiras, objeto de exposição em congresso interno da FADUSP, onde foi aprovada sem restrições, divulgada através do mencionado artigo publicado pela RDM e apresentada no foro da ATRIP em Genebra, acabou por encontrar eco em Resolução aprovada no último Congresso dessa associação internacional, realizado em Munique, em setembro de 1983. Vale a pena transcrever por inteiro o texto dessa Resolução, espe- 
rando seja adotada pelas universidades brasileiras, especialmente no seio da USP, localizada no Estado mais desenvolvido industrialmente de nosso País:

\section{Resolução}

A Associação Internacional para o Avanço do Ensino e Pesquisa em Propriedade Intelectual — ATRIP —, reunida em Munique aos 7 de setembro de 1983;

\section{I}

Reconhecendo que a proteção da propriedade intelectual pelo direito de patentes, desenhos e modelos industriais, marcas, concorrência desleal, variedades vegetais, direito de autor, transferência de tecnologia e repressão ao abuso do poder econômico representa um importante papel no desenvolvimento econômico, tecnológico e cultural de todos os paises e, em particular, dos paises em desenvolvimento;

Convencida que a criação, a administração, a defesa e a transferência eficazes dos direitos de propriedade intelectual pressupõem, principalmente, que o ensino e a pesquisa no campo da propriedade intelectual recebam a atenção apropriada das universidades e outras instituições educacionais;

Verifica que o ensino e a pesquisa no domínio da propriedade intelectual ao nível das universidades, embora varie de um país ao outro, não corresponde em geral ao papel econômico, tecnológico e cultural da propriedade intelectual e que este problema é particularmente sentido nos países em desenvolvimento;

Recebe com apreço os esforços das organizações internacionais e dos institutos e centros nacionais dedicados ao ensino e à pesquisa no campo da propriedade intelectual, que prestam assistência aos professores e pesquisadores nesse campo;

Resolve que os governos, as universidades e outras autoridades competentes de todos os países devem tomar as medidas apropriadas a fim de assegurar que o ensino e a pesquisa em matéria de propriedade intelectual se tornem partes integrantes e efetivas do processo educacional, atendendo assim à necessidade social de formar pessoal qualificado, capaz de compreender e de aplicar os conceitos e as instituições da propriedade intelectual no plano da política governamental e na prática científica, técnica, industrial e comercial, de modo a promover o progresso científico, econômico e cultural.

\section{I}

Recomenda sejam tomadas, para tal fim, as seguintes medidas:

- As universidades devem prever no quadro de suas faculdades de direito programas de ensino do direito de propriedade intelectual. 
Tal programa deve ser oferecido sob forma de cursos de introdução geral, abertos a todos os estudantes, e cursos suplementares e especializados sobre a propriedade industrial e o direito de autor, incluindo o direito de patentes, desenhos e modelos industriais, marcas, concorrência desleal, variedades vegetais, direitos de autor, transferência de tecnologia e repressão ao abuso ao poder econômico. Esses cursos especializados devem ser oferecidos ao menos como cursos opcionais ao nível de graduação e pós-graduação e devem ser reconhecidos para a obtenção de títulos e graus;

- O ensino deve levar em conta os aspectos internacionais e regionais da propriedade intelectual, bem como suas implicações econômicas, sociais e culturais;

- O ensino do direito da propriedade intelectual não deve ser limitado às universidades, particularmente às faculdades de Direito. Este ensino deve ser oferecido igualmente por outras faculdades, especialmente faculdades de ciências sociais e econômicas e por instituições de ensino técnico que formam engenheiros e pessoal técnico e científico e por outras escolas que cuidem da formação de pessoas ligadas à criação dos diferentes objetos da propriedade intelectual, como academias de arte, de cinema, etc.;

- É necessário pôr à disposição das universidades e outras instituições ligadas ao ensino e à pesquisa em propriedade intelectual o material necessário e suficiente para o ensino, o estudo e a pesquisa;

- Devem-se estabelecer e desenvolver contatos entre as instituições de ensino e pesquisa de um lado e os organismos públicos de administração da propriedade intelectual de outro lado, ou seja, os órgãos de patentes e de direito de autor. Esses contatos devem ser estabelecidos e desenvolvidos igualmente entre as instituições de ensino e pesquisa de um lado e os profissionais de propriedade intelectual e. suas organizações profissionais de outro lado, como os inventores, autores, artistas, advogados, agentes de patentes e juízes;

- E necessário tornar possivel aos professores e pesquisadores, em particular pela concessão de bolsas, estudar as experiências e problemas específicos de outros países; devem-se criar possibilidades de trocas de pontos de vistas e de experiências nos congressos e reuniões internacionais;

- Os programas nacionais e internacionais de cooperação para o desenvolvimento devem incluir medidas destinadas a facilitar o intercâmbio de professores e pesquisadores entre países desenvolvidos e em desenvolvimento e devem prever medidas para pôr à disposição dos professores e pesquisadores de países em desenvolvimento o material suficiente para o ensino e o estudo. 